\title{
Immunological and molecular epidemiological characteristics of acute and fulminant viral hepatitis A
}

\author{
Zahid Hussain ${ }^{1,2,3^{*}}$, Syed A Husain ${ }^{3}$, Fahad N Almajhdi ${ }^{2,4}$ and Premashis Kar $^{2}$
}

\begin{abstract}
Background: Hepatitis A virus is an infection of liver; it is hyperendemic in vast areas of the world including India. In most cases it causes an acute self limited illness but rarely fulminant. There is growing concern about change in pattern from asymptomatic childhood infection to an increased incidence of symptomatic disease in the adult population.
\end{abstract}

Objective: In-depth analysis of immunological, viral quantification and genotype of acute and fulminant hepatitis A virus.

Methods: Serum samples obtained from 1009 cases of suspected acute viral hepatitis was employed for different biochemical and serological examination. RNA was extracted from blood serum, reverse transcribed into cDNA and amplified using nested PCR for viral quantification, sequencing and genotyping. Immunological cell count from freshly collected whole blood was carried out by fluorescence activated cell sorter.

Results: Fulminant hepatitis A was mostly detected with other hepatic viruses. CD8 ${ }^{+} T$ cells count increases in fulminant hepatitis to a significantly high level $(P=0.005)$ compared to normal healthy control. The immunological helper/suppressor $\left(\mathrm{CD}^{+} / \mathrm{CD}^{+}\right)$ratio of fulminant hepatitis was significantly lower compared to acute cases. The serologically positive patients were confirmed by RT-PCR and total of $72(69.2 \%)$ were quantified and sequenced. The average quantitative viral load of fulminant cases was significantly higher $(P<0.05)$. There was similar genotypic distribution in both acute and fulminant category, with predominance of genotype IIIA (70\%) compared to IA (30\%).

Conclusions: Immunological factors in combination with viral load defines the severity of the fulminant hepatitis A. Phylogenetic analysis of acute and fulminant hepatitis A confirmed genotypes IIIA as predominant against IA with no preference of disease severity.

Keywords: acute hepatitis A fulminant hepatitis A, genotype, viral load, RT-PCR

\section{Background}

Hepatitis A virus (HAV) is one of the common causative agents for acute hepatitis worldwide, particularly in developing countries where $20-25 \%$ of clinical hepatitis is caused by HAV infection [1,2]. Hepatitis $A$ is an acute infection with generalized symptoms accompanied by jaundice and it represents mainly a disease of the pediatric population $[3,4]$. In children, the infection with

\footnotetext{
* Correspondence: hussainzahep@gmail.com

${ }^{1}$ PCR Hepatitis Laboratory, Department of Medicine, Maulana Azad Medical College, New Delhi, 110002, India

Full list of author information is available at the end of the article
}

HAV is generally asymptomatic while exposure of nonimmune adolescents and adults may results in severe clinical disease like fulminant hepatic failure (FHF) [2,5-7]. The pathogenetic mechanisms underlying hepatocellular injury in acute hepatitis are poorly understood [8]. There is general agreement that HAV infection does not evolve to chronic hepatitis in man and immune mechanisms have been suspected of playing a major role in eliminating virus infected liver cells $[9,10]$.

HAV presents a spherical virion with $27 \mathrm{~nm}$, with $7.5 \mathrm{~kb}$ linear, positive-sense RNA within the Picornaviridae family that demonstrates little antigenic variability $[11,12]$.

\section{Biomed Central}


HAV has been shown to possess a single conserved immunogenic neutralization site and isolates from different parts of the world belong to a single serotype [12,13]. It is composed of a $5^{\prime}$ non-coding region (NCR), structural protein regions, non-structural protein regions and a 3' NCR [14,15]. HAV genome is of positive polarity, i.e., viral RNA can directly serve as messenger RNA [16]. The large open reading frame present in HAV genome can be divided into three (P1-P3) functional regions. The P1 region encodes capsid polypeptides VP1-VP3 and the putative VP4. The P2 and P3 regions encode nonstructural proteins which are necessary for virus replication (Figure 1) [17]. The nucleotide sequence comparison based on the VP1/2A region of the genome has been used to define seven different genotypes [15]. The seven genotypes are differentiated into four human clusters (I-III and VII) and three simian strains (IV-VI) [15]. The seven genotypes recovered from human and non-human primates differ from each other at approximately 15 to $25 \%$ of base position in the $\mathrm{VP} 1 / 2 \mathrm{~A}$ region [15]. The $\mathrm{VP} 1 / 2 \mathrm{~A}$ region is best suited for genotyping due to its relative variability compared with the VP3 and 5' nontranslated regions [15]. The nucleotide diversity within sub-genotypes of HAV (IA, IB, IIIA and IIIB) is less than $7.5 \%$ [15]. Most of the human strains cluster in genotype I, which has been further divided in sub-genotypes IA and IB. Sub-genotype IIIA had been reported to be the major HAV genotype in India [18-20]. However, recent report contradicts earlier findings that revealed sub-genotype IB in western India from samples of sewage treatment plant [19].

HAV is hyperendemic in India and most of the population is infected asymptomatically in early childhood with lifelong immunity [21]. However, recently due to altered epidemiology and decreasing endemicity the pattern of acute HAV infection is changing from asymptomatic childhood infection to an increased incidence of symptomatic disease in the adult population [21-23]. Although HAV is undergoing epidemiological changes in India, there are very few in-depth characterizations of all the causative factors related to HAV infection. Therefore, the aim of this study was to undertake an indepth analysis of immunological, viral quantification and genotype of acute and fulminant hepatitis A virus.

\section{Materials and methods}

\subsection{Patients and blood samples}

All those patients attending the medical out patients department (OPD) of Lok Nayak Hospital, New Delhi, with the characteristic symptoms of jaundice, fever, general malaise, fatigue, nausea, vomiting, anorexia and right upper quadrant discomfort were enrolled in this study. This has been approved by the ethical committee of Maulana Azad Medical College, New Delhi, as directed by the Declaration of Helsinki in 1995. Ten milliliters of blood sample was taken by venipuncture after informed consent of the patients, while children and adolescents consent was obtained from their parents and guardians.

\subsection{Diagnosis of acute and fulminant hepatitis A}

The clinical onset of an acute viral hepatitis (AVH) $A$ is defined as the beginning of early symptoms including fever, general malaise, fatigue, nausea, vomiting, anorexia and right upper quadrant discomfort. It is mainly characterized by the onset of jaundice and positive serological test for IgM anti-HAV. Fulminant hepatitis A is defined as clinical syndrome develops as a result of severe impairment of hepatic functions or massive necrosis of hepatocytes in the absence of preexisting liver disease. Fulminant hepatic failure (FHF) patients were diagnosed by the presence of encephalopathy within 4 weeks of onset of illness with a prothrombin time (PT) of less than $40 \%$ that of the standardized value $[16,24]$.

\subsection{Epidemiological survey}

Each person enrolled in this study gave personal information including general data, such as gender, age, onset of illness, past history of hepatitis, alcoholism, and

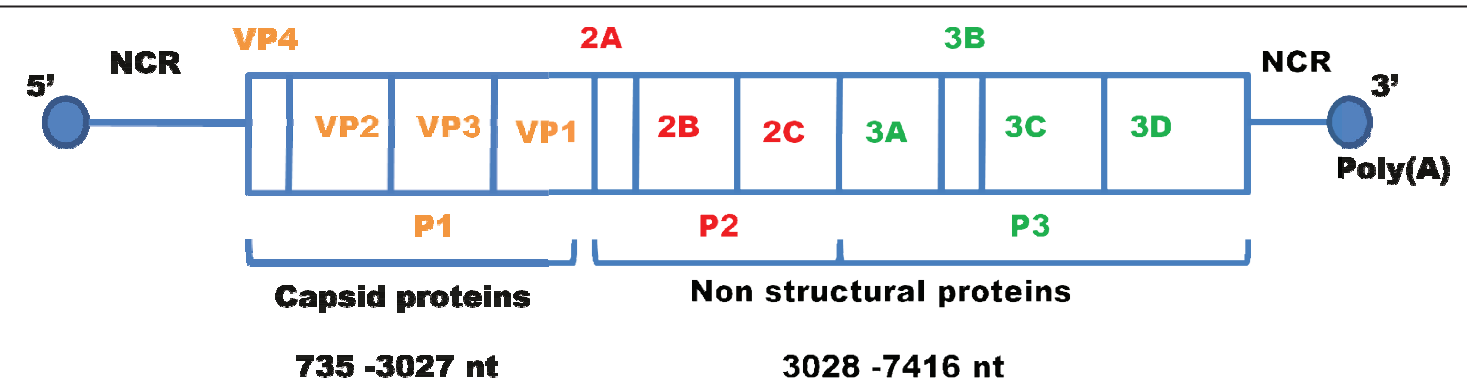

Figure 1 Genomic structure of hepatitis A virus. HAV genome is divided into a $5^{\prime}$ non-coding region (5'NCR), a giant open reading frame, and a non-coding region ( $\left.3^{\prime} \mathrm{NCR}\right)$. The coding region is subdivided into regions P1, P2 and P3. Adapted from: Totsuka and Moritsugu; Intervirology 1999; 42: 63. 
presence of major systemic disease. Those AVH patients who had positivity for any of IgM anti-HEV, hepatitis B surface antigen (HBsAg), IgM antibody to hepatitis B core antigen (IgM anti-HBc), and hepatitis $\mathrm{C}$ virus antibodies were excluded. Since fulminant hepatitis A is rare occurrence, we have reported all the FHF cases including cases with other hepatic viruses $(60 \%$ in this study). Patients with a history of recent exposure to drugs and those who had a heavy alcohol intake were also excluded from the study. The travel history within 3 months before the onset of illness was carefully checked and recorded, as incubation period for HAV is 2-8 weeks.

\subsection{Serological tests}

A total of $1009 \mathrm{AVH}$ and FHF patients were screened for IgM anti-HAV. In laboratory examination, serum albu$\mathrm{min} /$ globulin, alanine aminotransferase (ALT), aspartate aminotransferase (AST), alkaline phosphatase (ALP), total protein and total and direct bilirubin levels were measured. IgM anti-HAV was detected by enzyme immunoassay ELISA (HAVAB-MEIA, Abbott Laboratories, North Chicago, IL) according to the manufacturer's instructions. To determine other acute viral hepatitis, sera were also tested for IgM anti-HEV (Qiagen, Hilden, Germany), hepatitis B surface antigen (Qiagen, Hilden, Germany), IgM anti-HBc (Abbot Laboratories, North Chicago, IL), anti-HCV (Qiagen, Hilden, Germany) using Kits.

\subsection{FACS analysis of T-lymphocyte profile}

One milliliter of whole blood was collected from patients into a vial containing EDTA and was employed for $\mathrm{CD}^{+}$( $\mathrm{T}$ helper) and $\mathrm{CD}^{+}$( $\mathrm{T}$ suppressor) cell counts within 24 hours of collection using fluorescence activated cell sorter (FACS) (Becton Dickenson Electronics Laboratory, Mountain View, California). This system quantifies $\mathrm{CD}^{+}, \mathrm{CD}^{+}$and $\mathrm{CD}^{+} \mathrm{T}$ lymphocytes as absolute numbers of lymphocytes per $\mu \mathrm{l}\left(\mathrm{mm}^{3}\right)$ of blood, and the $\mathrm{CD}^{+} / \mathrm{CD}^{+} \mathrm{T}$ lymphocyte ratio. Samples from healthy controls were also run for cell counts using the manufacturer's protocol and reagents.

\subsection{HAV RNA detection}

RNA was extracted from each test sample, using the QIAamp viral RNA extraction kit (Qiagen, Germany) and reverse transcribed into cDNA using published primer [25]. The cDNA was then amplified in a nested PCR targeting VP1/2A region as shown in figure $1[26]$. Nested PCR was carried out using primers BR-5b (5'TTG TCTGTC ACA GAA CAA TCAG-3') as the outer, sense primer, BR-9b as the outer, anti-sense primer, RJ3c (5'-TCC CAG AGC TCC ATT GAA-3') as the inner, sense primer, and Br-6b (5'-AGG AGG TGG AAG CAC TTC ATT TGA-3') as the inner, anti-sense primer [25].
Both amplification reactions were performed in a 9600 thermo-cycler (Perkin-Elmer Cetus, Norwalk, CT) set to run for $2 \mathrm{~min}$ at $95^{\circ} \mathrm{C}$ (denaturation), $1 \mathrm{~min}$ at $55^{\circ} \mathrm{C}$ (primer annealing) and $1 \mathrm{~min}$ at $72^{\circ} \mathrm{C}$ (extension) for 35 cycles, with a final extension step at $72^{\circ} \mathrm{C}$ for $10 \mathrm{~min}$. After electrophoresis in 2\% agarose (Research Organics, Cleveland, $\mathrm{OH}$ ) and staining with ethidium bromide, a ultra-violet transilluminator (Gel Doc 1000, Bio-Hercules, CA) was used to check for the expected, 234 bp band.

\subsection{Direct sequencing}

The target PCR products within the agarose gel were purified for sequencing using the perfect prep Gel Cleanup Kit (Eppendorf, Westbuty, NY), according to the manufacturer's specifications, and subjected to $2 \%$ agarose gel electrophoresis in order to ascertain their purity. Between 10 and $30 \mathrm{ng} / \mu \mathrm{l}(3-6 \mu \mathrm{l})$ of each DNA sample was subjected to cycle sequencing using $8 \mu \mathrm{l}$ of dye terminator from a DNA sequencing kit (Big Dye Terminator V.3.0 Cycle Sequencing Ready Reaction, Foster City, CA) and 3.2 pmole of specific primer (in a final reaction volume of $20 \mu \mathrm{l})$ in a thermocycler $(9600$ Perkin-Elmer Cetus, Norwalk, CT). This round of amplification was performed according to the manufacturer's specifications, using primer BR-5b to amplify the particular DNA strand of interest for further sequencing. The extension products were subsequently purified from excess unincorporated dye terminators by ethanol precipitation, according to the manufacturer's specifications (ABI Sequencing kit, ABI, Foster City, CA), and subjected to sequence analysis by the ABI Prism 310 Genetic Analyzer (ABI, Foster City, CA).

\subsection{Primers, probe and standard for real-time amplification}

Viral RNA was amplified using primers derived from the most constant region, the $5^{\prime}$ non-coding region ( 5 'NCR) as shown in figure 1. The primers used were, forward primer HAV-1 (5'-TTTCCGGAGCCCCTCTTG-3'), as wild type (M14707) reverse primers HAV-2 (5'-AAA GGGAAATTTAGCCTATAG CC-3') and HAV-3 (5'AAAGGGAAAATTTAGCCTATA GCC-3'), and HAVProbe (5'-FAM-ACTTGATACCTCACCGCCGTTTG CCT-TAMRA-3') and RNA standard representing the 5 'NCR region was constructed according to CostaMattioli et al. [27]. RT-PCR was carried out with a HAV quantification kit (Roche Diagnostics GmbH, Germany) according to the manufacturer's instructions. The total volume of the reaction mixture was $25 \mu \mathrm{l}(15 \mu \mathrm{l}$ of master mix with $10 \mu \mathrm{l}$ of the RNA template) in $0.2 \mathrm{ml}$ tubes. The capillaries were sealed, centrifuged, and transferred to the Rotor Gene 3000 real-time PCR machine (Corbett Research, Sydney, Australia). Reversetranscription was done for $15 \mathrm{~min}$ at $50^{\circ} \mathrm{C}$ followed by 
5 min denaturation at $95^{\circ} \mathrm{C}$. The corresponding cDNA's were amplified by PCR $\left(20 \mathrm{~s}\right.$ at $95^{\circ} \mathrm{C}, 30 \mathrm{~s}$ at $50^{\circ} \mathrm{C}$ acquiring FAM, and $20 \mathrm{~s}$ at $72^{\circ} \mathrm{C}$ ) over 45 cycles, and an $87 \mathrm{bp}$ fragment was obtained. The CT values from the clinical samples were plotted on the standard curve, and the number of copies was calculated automatically.

\subsection{Phylogenetic analysis and genotype determination}

The HAV genome shows a high degree of stability, but the VP1/2A junction region is recognized as one of the most variable regions. The location of VP1/2A junction region in HAV genome is shown in Figure 1, and chosen for genotyping and phylogenetic analysis. Website http://www. phylogeny.fr was used for reconstructing and analyzing phylogenetic relationships between different HAV Indian isolates. The HAV Indian isolates were amplified and sequenced from clinical samples and compared with the corresponding GeneBank reference sequences for genotypes I-III, IV, VI, \& VII are provided in additional file 1. The GeneBank sequence accession numbers of studied hepatitis A virus sequences which constitute phylogenetic tree are incorporated in figure legends 4 and 5 and published sequences in additional file 2 .

\subsection{Statistical analysis}

Chi-squared analysis, Fisher's exact test, Student's $t$-test, Mann-Whitney $U$-test, Wilcoxin two-sample test, ANOVA and stepwise backward Cox regression procedure were used in this study. A $P$ value of $<0.05$ was considered significant.

\section{Results}

Total of 1009 acute and fulminant viral hepatitis cases were screened during the period of 5 years, 556 were males and 453 females with sex ratio 1.2:1. The mean age and standard deviation of the patients were $28.2 \pm$ 21.8 years.

\section{1a Serological screening of acute and fulminant hepatitis A}

Out of one thousand and nine hundred acute cases, 104 (10.3\%) were positive for IgM anti-HAV by commercially available ELISA kit. Out of 104 HAV-IgM positive cases, 10 (0.96\%) developed into fulminant hepatitis A. Other viral etiologies were detected in $60 \%$ of HAV fulminant cases as shown in Table 1.

\section{1b Sensorium/hepatic encephalopathy of fulminant hepatitis $A$}

Fifty percent of the fulminant hepatitis A patients fall under clinical grade I hepatic encephalopathy. These patients were restless and had almost uncomplicated course and recovered completely. One patient in grade II hepatic encephalopathy was restless and confused but
Table 1 Acute and fulminant HAV patients infected with other etiological agents

\begin{tabular}{|c|c|c|}
\hline Etiological agents & $\begin{array}{c}\mathrm{AVH}^{\mathrm{a}} \\
(\mathrm{n}=94)\end{array}$ & $\begin{array}{c}\text { FHF }^{b} \\
(n=10)\end{array}$ \\
\hline $\mathrm{HBsAg}^{\mathrm{C}}+\operatorname{IgM}$ anti-HBC${ }^{d}$ & 03 & 02 \\
\hline Anti-HCV ${ }^{e}$ & - & 01 \\
\hline HEV-lgM ${ }^{f}$ & 05 & - \\
\hline HEV-lgM ${ }^{f}+\mathrm{HBsAg}^{c}$ & - & 01 \\
\hline HEV-IgM ${ }^{f}+$ Anti-HCV ${ }^{d}$ & - & 02 \\
\hline
\end{tabular}

${ }^{\mathrm{a}} \mathrm{AVH}=$ Acute viral hepatitis; ${ }^{\mathrm{b}} \mathrm{FHF}=$ Fulminant hepatic failure; ${ }^{\mathrm{c}} \mathrm{HBsAg}=$ hepatitis B surface antigen; ${ }^{d} \operatorname{lgM}$ anti-HBC $=$ Hepatitis B core antibody; ${ }^{\text {e }}$ Anti$\mathrm{HCV}=$ Hepatitis $\mathrm{C}$ virus antibody; ${ }^{\mathrm{f}} \mathrm{HEV}-\mathrm{IgM}=$ Hepatitis $\mathrm{E}$ virus antibody.

recovered finally. Four patients died of hepatic encephalopathy, three due to grade IV hepatic encephalopathy. These patients were in coma and cannot be aroused. While patient of hepatic encephalopathy grade III developed drowsy and confused state and died due to complications. The duration of hepatic encephalopathy among survivors and non-survivors were similar $(P>$ 0.03). Encephalopathy developed within 1-4 weeks of onset of symptoms, and mean duration between onset of symptoms and encephalopathy was $6.3 \pm 0.3$ days.

3.1c Biochemical profile of acute and fulminant hepatitis $A$ Mean haemoglobin $(\mathrm{g} / \mathrm{dl})$ was significantly lesser in acute and fulminant hepatitis A compared to healthy control, while difference between acute and fulminant hepatitis A cases was statistically significant $(P<0.035)$. Similarly, prothrombin time was higher among fulminant cases compared to acute viral hepatitis $\mathrm{A}(P<$ 0.04 ) as shown in additional file 3 . The liver function profiles of acute and fulminant hepatitis $\mathrm{A}$ at different days of follow up as shown in additional file 4. Liver function profiles (ALT, AST and ALP) of fulminant hepatitis A at different days of follow up were significantly higher compared to acute viral hepatitis A. In acute cases the above values decreased from initial to final days but not FHF. Total bilirubin was similar ( $\mathrm{P}=$ $0.55)$ at initial day, but at $1^{\text {st }}$ week of the onset of jaundice total bilirubin was quite higher $(\mathrm{P}=0.002)$ in the fulminant category compared to the acute cases. The rest of the liver function parameters (TB, DB/IB, ALP, $\mathrm{TP}$, and $\mathrm{Alb}$ ) were not statistically significant.

\subsection{Epidemiological profile of acute and fulminant hepatitis $A$}

The epidemiological characterization of acute and fulminant hepatitis was similar with no significance. Twenty one patients (33.8\%) in the acute category had history of being exposed to unhealthy surroundings with poor sanitation facilities compared to $3(30 \%)$ in fulminant hepatitis A as shown in Table 2. Travel to high endemic area was also found to be a major cause that leads to 
Table 2 Epidemiological characteristics of acute and fulminant hepatitis A

\begin{tabular}{lcc}
\hline Characteristics & $\begin{array}{c}\mathbf{A V H}^{\mathbf{a}} \\
(\mathbf{n}=\mathbf{9 4})\end{array}$ & $\begin{array}{c}\mathbf{F H F}^{\mathbf{b}} \\
(\mathbf{n}=\mathbf{1 0})\end{array}$ \\
\hline Travel history & $13(13.8 \%)$ & $1(10 \%)$ \\
Unhygienic condition & $32(34.0 \%)$ & $3(30 \%)$ \\
\hline
\end{tabular}

${ }^{\mathrm{a}} \mathrm{AVH}=$ Acute viral hepatitis; ${ }^{\mathrm{b}} \mathrm{FHF}=$ Fulminant hepatic failure.

Travel history; AVH vs FHF: $\mathrm{P}=0.98$ Unhygienic condition; AVH vs FHF: $\mathrm{P}=$ 0.87. Mann-Whitney $U$-test was applied to find the statistical difference between the above groups. $P$ value $<0.05$ is statistically significant, so the $P$ value is not significant.

spread of hepatitis A virus. Eight (13\%) acute cases and one $(10 \%)$ fulminant hepatitis A patient had travel history $(\mathrm{P}=0.98)$.

\subsection{Immunological profiles of acute and fulminant hepatitis $A$}

The lymphocyte sub-population (i.e. $\mathrm{CD}^{+}$(helper) $/ \mathrm{CD} 8^{+}$ (suppressor) ratio of acute and fulminant hepatitis A was compared with normal healthy control. CD ${ }^{+} \mathrm{T}$ cells count increases in fulminant and acute hepatitis cases compared to normal healthy control, but this increase was significant only in the first case $(P=0.005$ and 0.074$)$. In acute and fulminant hepatitis cases, $\mathrm{CD}_{4}^{+} \mathrm{T}$ cells concentration (cells/microliters) maintained a low level compared to normal healthy control as shown in Figure 2. In fulminant hepatitis cases helper/suppressor T-lymphocyte ratio decreased to a significant quantity compared to the ratio observed among normal control as shown in Figure 3. $\mathrm{CD}^{+}$(cytotoxic $\mathrm{T}$ lymphocytes) concentration (cells/ microliters) increases to target the infected (hepatocytes),

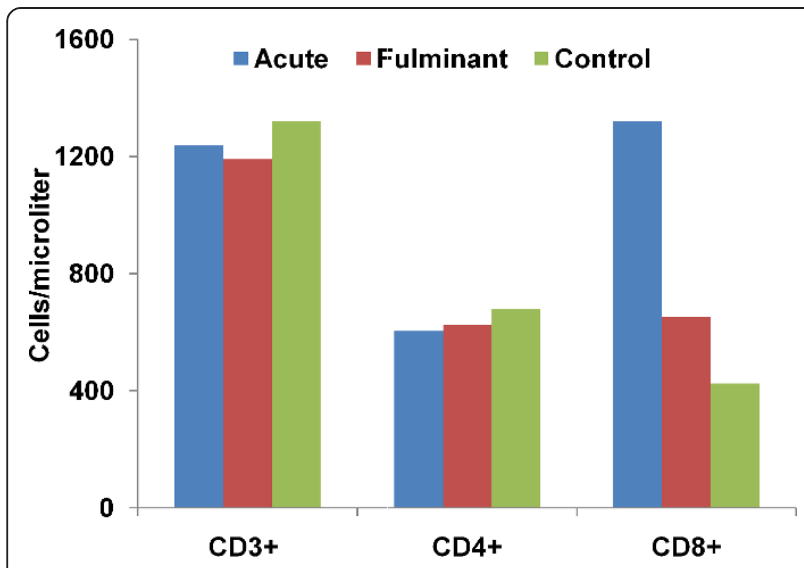

Figure 2 FACS analysis of T lymphocytes showing lymphocytes counts acute (AVH), fulminant (FHF) and normal healthy control (C). Mann-Whitney U-test was applied to find the statistical difference between the above groups. $\mathbf{C D}^{+}$; AVH vs FHF: $\mathbf{P}=0.864$, AVH vs $C: \mathbf{P}=0.297$, FHF vs C: $\mathbf{P}=1.000 \mathbf{C D 4}^{+} ;$AVH vs FHF: $\mathbf{P}=$ 0.434 , AVH vs C: $\mathbf{P}=0.086$, FHF vs C: $\mathbf{P}=0.135, \mathbf{C D}^{+} ; \mathrm{AVH}$ vs FHF: $\mathbf{P}=0.244$, AVH vs C: $\mathbf{P}=0.074$, FHF vs C: $\mathbf{P}=0.000$.

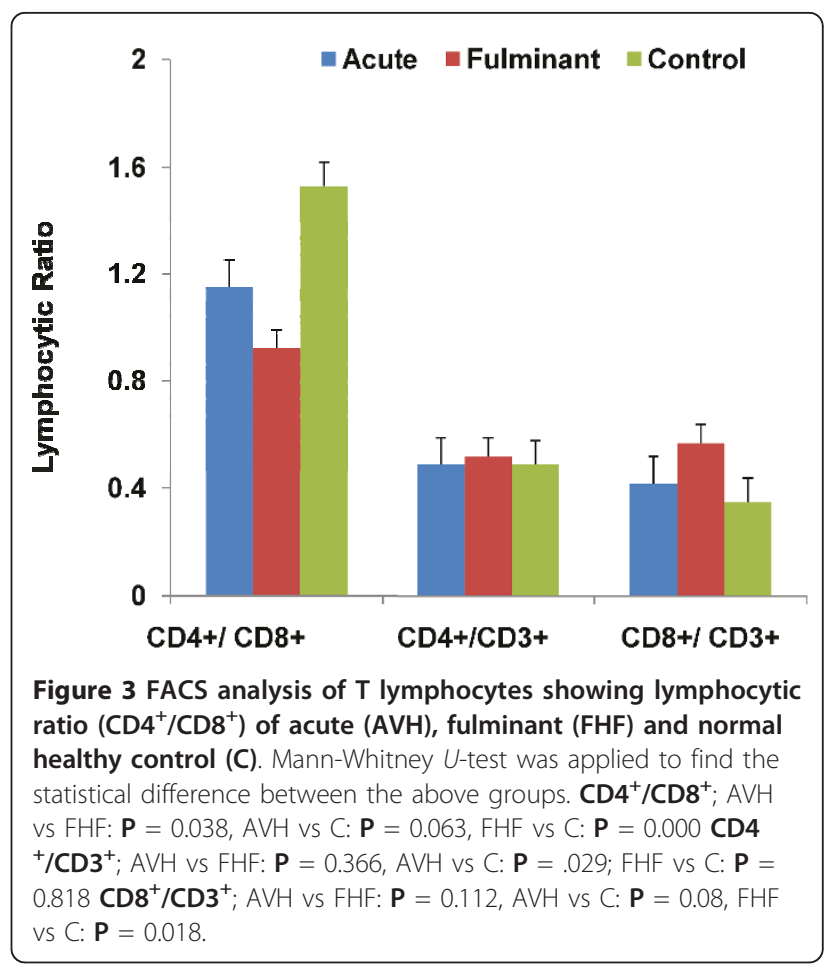

while $\mathrm{CD}^{+} \mathrm{T}$ lymphocytes decline, resulting in the helper suppressor ratio and hence immunity.

\subsection{Molecular analysis of serologically positive samples} All IgM anti-HAV positive samples (104) were analyzed for HAV RNA presence to correlate the time of presentation of the disease with HAV-RNA positivity. Fifty eight (56\%) of AVH cases turned positive for RT-PCR, reported to OPD at 0-7 days of onset of jaundice. This includes fulminant hepatic failure following the acute illness. The positivity by RT-PCR in acute and fulminant was $75 \%$ and $100 \%$ respectively as shown in Table 3. HAV RNA detection was higher in fulminant hepatitis cases compared to that observed among acute cases. Thirty two patients positive for hepatitis A by ELISA turned to OPD in $2^{\text {nd }}$ week of the onset of jaundice. Again the positivity of fulminant case was $100 \%$, while in acute case the positivity declined to $62 \%$. The RNA

Table 3 Correlation between HAV RNA positivity with respect to duration of jaundice

\begin{tabular}{ccc}
\hline Duration of Jaundice & $\begin{array}{c}\text { HAV RNA AVH } \\
(\mathbf{n}=\mathbf{6 2})\end{array}$ & $\begin{array}{c}\text { HAV RNA FHF } \\
(\mathbf{n}=\mathbf{1 0})\end{array}$ \\
\hline 0-7 days & $38 / 51(74.5 \%)$ & $07 / 07(100 \%)$ \\
7-14 days & $18 / 29(62.0 \%)$ & $03 / 03(100 \%)$ \\
1-2 months & $05 / 11(45.4 \%)$ & - \\
5 months & $01 / 03(33.3 \%)$ & - \\
\hline
\end{tabular}

${ }^{a}$ AVH $=$ Acute viral hepatitis; ${ }^{b}$ FHF = Fulminant hepatic failure. There was significant difference $(p<0.05)$ between final positivity of acute and fulminant hepatitis $A$. 
positivity of patients who turned to the OPD in $1^{\text {st }}$ and $2^{\text {nd }}$ months of the onset of jaundice again declined. There was significant difference $(P>0.05)$ between final positivity of acute and fulminant hepatitis. All the positive acute and fulminant cases were directly sequenced to determine the genotype(s).

\section{6a Phylogenetic analysis and genotype distribution of hepatitis $A$ virus}

Accommodating large number of sequenced samples (reference and studied sequences) in one phylogenetic tree lacks clarity, therefore for most accurate presentation 2 phylogenetic trees have been constructed as shown in Figure 4 and 5 . The genotype of Indian HAV isolates was derived by neighbor-joining phylogenetic tree of hepatitis A virus sequences based on the VP1/2A region. According to phylogenetic analysis, acute cases were divided into genotype IA and IIIA. There was predominance of genotype IIIA with $74 \%$ of the total cases sequenced. In fulminant hepatitis A cases, genotype IIIA again was also prevalent $(70 \%)$ as shown in Table 4 . Between the groups the genotype was similarly distributed but within the two groups the prevalence was quite significant.

\subsection{Viral load determination among acute and fulminant hepatitis A}

All the patients (acute and fulminant hepatitis A) were quantified for viral load by real-time polymerase chain

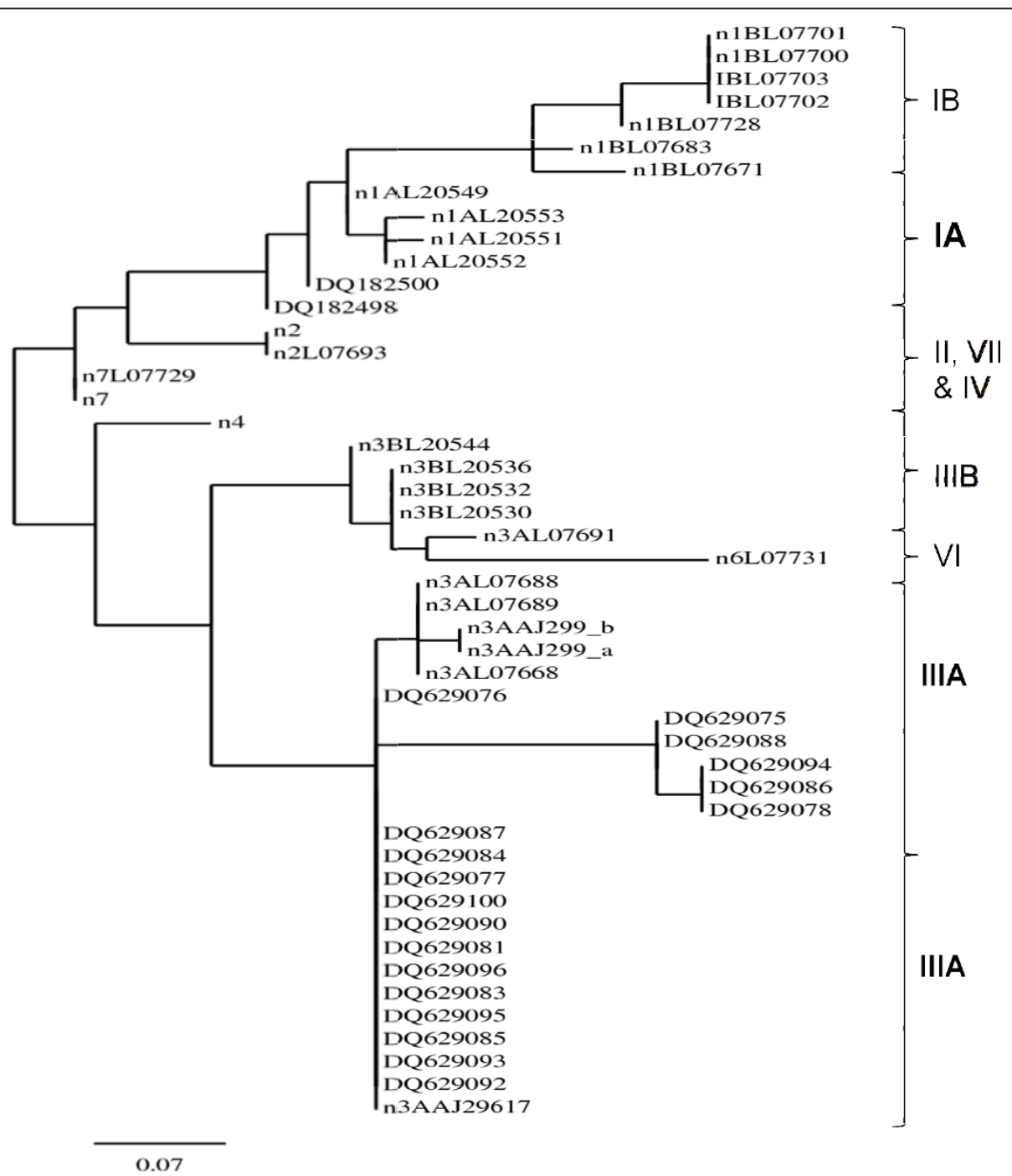

Figure 4 A neighbor-joining phylogenetic tree of genetic relatedness among isolates of hepatitis $A$ virus based on the sequencing of the VP1/2A region. Isolates DQ182500, DQ182498, DQ629076, DQ629075, DQ629088, DQ629094, DQ629086, DQ629078, DQ629087, DQ629084, DQ629077, DQ629100, DQ629090, DQ629081, DQ629096, DQ629083, DQ629095, DQ629085, DQ629093 and DQ629092 were collected during this study, in PCR Hepatitis Laboratory, MAM College and associated LNJ Hospital, New Delhi, India. The phylogenetic analysis revealed that the Indian isolates belong to genotypes IA and predominant III A. 


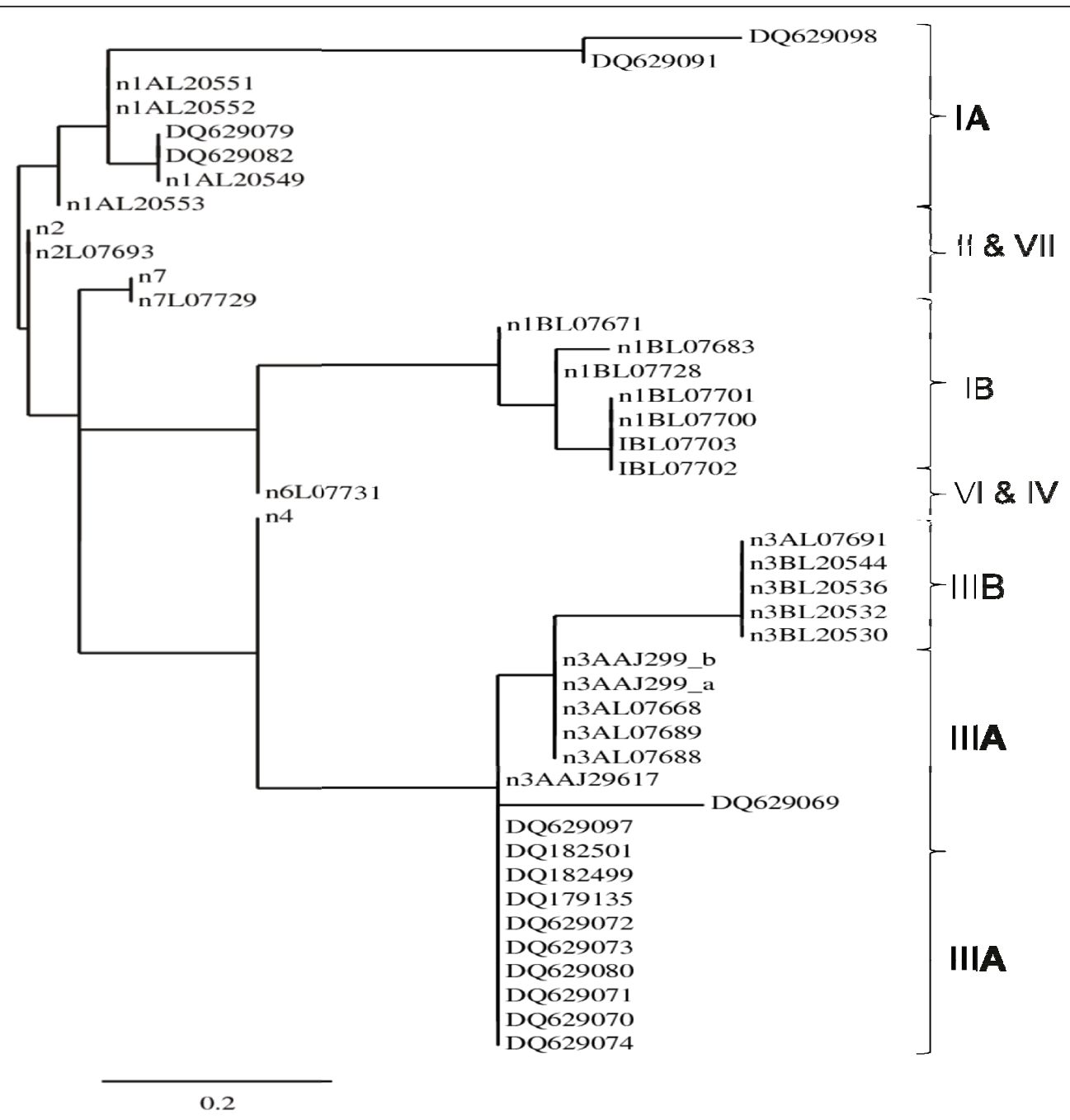

Figure 5 A neighbor-joining phylogenetic tree of genetic relatedness among isolates of hepatitis $A$ virus based on the sequencing of the VP1/2A region. Isolates DQ629098, DQ629091, DQ629079, DQ629082, DQ629069, DQ629097, DQ182501, DQ182499, DQ179135, DQ629072, DQ629073, DQ629080, DQ629071, DQ629070 and DQ629074 were collected during this study, in PCR Hepatitis Laboratory, MAM College and associated LNJ Hospital, New Delhi, India. The phylogenetic analysis revealed that the Indian isolates belong to genotypes IA and predominant III A.

reaction. As shown in Figure 6, HAV viral load among fulminant cases was much higher compared to acute viral hepatitis A. According to the non parametric MannWhitney $U$-test, the calculated viral load concentration

Table 4 Comparison of genotype(s) between acute and fulminant hepatitis $A$ patients

\begin{tabular}{|c|c|c|c|}
\hline \multicolumn{2}{|c|}{$\mathrm{AVH}^{\mathrm{a}}(\mathrm{n}=62)$} & \multicolumn{2}{|c|}{$\mathrm{FHF}^{\mathrm{b}}(\mathrm{n}=10)$} \\
\hline \multicolumn{2}{|c|}{ Genotype (s) } & \multicolumn{2}{|c|}{ Genotype (s) } \\
\hline IA & IIIA & IA & IIIA \\
\hline $16(26 \%)$ & $46(74 \%)$ & $03(30 \%)$ & $07(70 \%)$ \\
\hline
\end{tabular}

${ }^{\mathrm{a}} \mathrm{AVH}=$ Acute viral hepatitis; ${ }^{\mathrm{b}} \mathrm{FHF}=$ Fulminant hepatic failure

Fisher's exact test was applied to find the statistical difference between the acute and fulminant groups. $P$ value calculated between the two groups was 0.52 , the value was statistically insignificant. of the fulminant patients was significantly quite higher compared to the acute viral hepatitis A patients.

\section{Discussion}

Human hepatitis A, a widespread infectious disease that is hyperendemic in vast areas of the world, results from the infection of the liver [3,28]. Humans are thought to be its principal host and represent a disease of pediatric population [28]. Importantly, one third of the patients in present study belong to age group 11-30 years which is quite different from the earlier findings that pediatric populations are more prominent [21]. HAV distribution pattern was in corroboration with earlier findings which showed male predominance and susceptibility to HAV infection compared to female population $[3,28]$. 


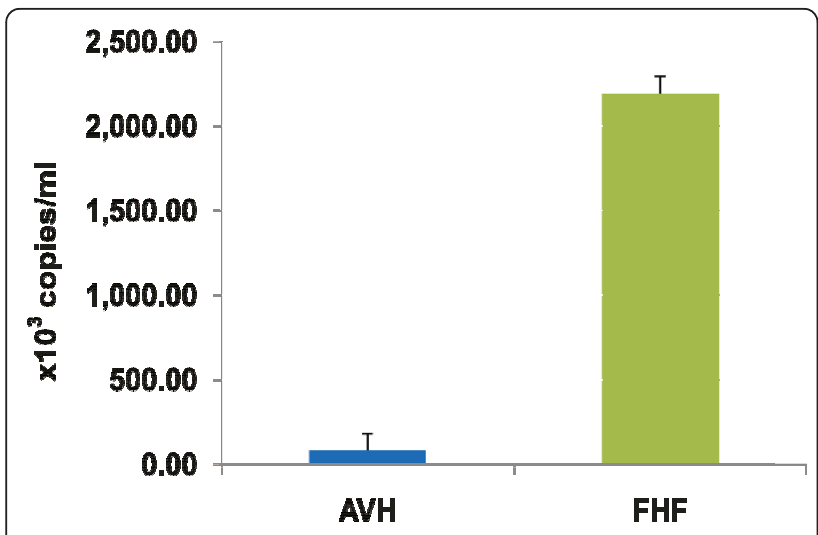

Figure 6 Viral load determination of acute and fulminant hepatitis A by real time PCR. Mann-Whitney U-test was applied to find the statistical difference between the above groups.

Quantitative viral load; AVH vs FHF: $P=0.0000$; highly significant.

The present study showed that one third of hepatitis A patients had insufficient sanitation or poor hygienic conditions with overcrowded population. As reported earlier, low standards of sanitation promote transmission of the virus, therefore, to avoid any outbreak of this infection in new entrants there is urgent need for proper sanitation $[29,30]$. Traveler's account for $10-13 \%$ of the acute and fulminant hepatitis A in this study, similar to the earlier reports which estimate an annual infection rate of 3.5-7.2 per 100 individuals [18,31].

$40 \%$ of death (non-survivors) and complications were related among hepatitis A cases presenting histology of III and IV, what was also demonstrated in other studies $[6,7]$. Most of the non-survivors were infected with other viral etiologies. The survivors of fulminant hepatitis A belong to Grade I and II with no infection with other viral hepatitis. Prothrombin time (PT) of fulminant hepatitis A cases were significantly prolonged compared to normal controls $(P=0.035)$. The reason why fulminant hepatitis A occurs in some patients and not in other remains unclear. HAV infection rarely has a fulminant course and is seldom fatal, with an estimated fatality rate of 0.14 to 2.0 percent [8], which corroborates the findings of the present study. Diagnosis of hepatitis A were usually made by LFTs and followed at different interval of time [31,32]. ALT, AST and ALP levels of fulminant viral hepatitis cases at different days of follow up was significantly higher compared to acute hepatitis A. This was similar to earlier findings that aminotransferase levels are sensitive markers of liver damage, and usually reach peak levels about the time the patients seek medical attention, although the degree of elevation does not appear to correlate the outcome [32-34].

The clearance of viral infection and the disease manifestations are associated with cellular immune response [34].
The relative percentage of $\mathrm{CD} 4^{+} \mathrm{T}$ lymphocytes decline and $\mathrm{CD} 8^{+} \mathrm{T}$ lymphocytes increases in the fulminant $\mathrm{HAV}$ cases results in decline of the helper/suppressor ratio. This decrease of $\mathrm{CD} 4^{+} / \mathrm{CD}^{+} \mathrm{T}$ lymphocyte ratio was highly significant compared to acute cases $(\mathrm{P}=0.038)$. This shows that low $\mathrm{CD}_{4}^{+} \mathrm{T}$ lymphocyte counts are associated with a variety of conditions in viral infections [35]. These findings were in corroboration with study carried out on patients with cervical intraepithelial neoplasia and invasive cancer revealed a decrease in CD4 cells with a relative increase in CD8 cell count, leading to a considerable reduction in the CD4/CD8 cell ratio [36]. Therefore the present study speculate that fulminant HAV infection may be triggered by diminished cellular immunity in susceptible patients and increase liver damage and hence fatality and severity.

The detection rate and mean duration of HAV viremia was $69.3 \%$ and 15 days (range 1-2 months) respectively [1]. This proves earlier findings that HAV RNA could be detected on an average 18 days following the onset of clinical symptoms [32,34]. The average viral load of fulminant hepatitis was significantly higher compared to the acute hepatitis A cases in the present study. Although HAV is not directly cytopathic, viral factor might be one reason involved in determining the severity of the disease [37]. Seven HAV genotypes have been defined based on the sequence of the VP1/2A junction region of a global collection of viruses [15]. HAV isolates reported from India were found to be of genotype IIIA [15]. However recent study from western India demonstrated presence of genotype IB [19]. Vaidya et al., study had limitation due to the collection of HAV isolates from sewage treatment plant and not directly from the patients [19]. The current study detected HAV RNA by using RT-PCR in the sera of patients instead of feces. The acute hepatitis A genotype (s) distribution was found to be IA (26\%) and IIIA (74\%). Similarly, fulminant hepatic genotype distribution was IA (30\%) and IIIA (70\%) with no significant difference between these groups $(P=0.52)$. Thus, it appears that the prevalence of HAV genotypes in Northern India is was different from western India, indicating there could be geographical variations in the prevalence of HAV genotypes $[15,18,19]$.

\section{Conclusions}

In summary, results suggest that hepatitis $\mathrm{A}$ is a major public health problem in India. Further, most hepatitis A cases reported was from poor hygienic surroundings, which emphasizes the need for improving the public health measures to prevent epidemics of hepatitis A. There was relative percentage of $\mathrm{CD} 4^{+} \mathrm{T}$ lymphocytes decline and $\mathrm{CD}^{+} \mathrm{T}$ lymphocytes increase in the fulminant HAV. This results in decline in helper/suppressor 
ratio that might lead to development of a weak antiviral immune response or diminished cellular immunity to the viral antigens. Significant increase of viral copies in fulminant patients defines its role in determining the severity of the disease. Phylogenetic analysis of acute and fulminant hepatitis A confirmed genotypes IIIA as predominant against IA with no preference of disease severity. Finally, both viral and host factors should be considered and examined when discussing the mechanisms responsible for the severity of type A hepatitis.

\section{Competing interests}

The authors declare that they have no competing interests.

\section{Authors' contributions}

$\mathrm{ZH}$, PK participated in study design. ZH participated in sample collection, experimentation. $\mathrm{ZH}, \mathrm{SAH}$, and PK participated in data analysis. FNA edited the manuscript. All authors read and approve the final manuscript.

\section{Additional material}

Additional file 1: GeneBank reference sequences. The sequenced HAV north Indian isolates were compared with different reference sequences representing genotypes: I-III, IV, VI, \& VII.

Additional file 2: Hussain et al., published sequences with GeneBank accession number. Hussain et al., published sequences which were categorized into genotype IA and IIIA. These north Indian isolates of hepatitis A virus were characterized based on the sequencing of the VP1/2A region.

Additional file 3: Haemoglobin and prothrombin time of acute and fulminant hepatitis $\mathbf{A}$. The mean haemoglobin and prothrombin time of acute and fulminant hepatitis A patients were compared with the normal healthy control.

Additional file 4: The follow up of liver function profile of acute and fulminant hepatitis $\mathrm{A}$. Liver function profile of acute and fulminant hepatitis A patients were followed at different days and weeks.

\section{Acknowledgements}

The authors extend their appreciation to the Deanship of Scientific Research at King Saud University for funding the work through the research group project number: RGP-VPP-136. We are also thankful to Centre of Excellence in Biotechnology Research, King Saud University, Saudi Arabia for technical support and PCR Hepatitis Laboratory, Department of Medicine and Pediatrics, Maulana Azad Medical College, New Delhi for sample collection, storage and processing.

\section{Author details}

'PCR Hepatitis Laboratory, Department of Medicine, Maulana Azad Medical College, New Delhi, 110002, India. ${ }^{2}$ Center of Excellence in Biotechnology Research, King Saud University, P.O. Box 2460, Riyadh, 11451, Saudi Arabia. ${ }^{3}$ Human Genetics Laboratory, Department of Biosciences, Jamia Millia Islamia, New Delhi, 110025, India. ${ }^{4}$ Department of Botany and Microbiology, College of Science, King Saud University, P.O. Box 2455, Riyadh 11451, Saudi Arabia.

Received: 27 February 2011 Accepted: 23 May 2011

Published: 23 May 2011
References

1. Kwon OS, Byun KS, Yeon JE, Park SH, Kim JS, Kim JH, Bak YT, Kim JH, Lee CH: Detection of hepatitis A viral RNA in sera of patients with acute hepatitis A. J Gastroenterol Hepatol 2000, 15:1043-1047.

2. Yotsuyanagi H, Koike K, Yasuda K, Moriya K, Shintani Y, Fujie H, Kurokawa K, lino S: Prolonged fecal excretion of hepatitis $A$ virus in adult patients with hepatitis $\mathrm{A}$ as determined by polymerase chain reaction. Hepatology 1996, 24:10-13.

3. Chadha MS, Chtambar SD, Shaikh NJ, Arankalle VA: Exposure of Indian children to hepatitis A virus and vaccination age. Ind J Med Res 1999, 9:11-15.

4. Schwarz KS, Balistreri WF: Viral hepatitis. In: Pediatric Liver Research Agenda 2000: A blueprint for the future. Developed by the Children's Liver Council R.J. Sokol, Chair, NJ: American Liver Foundation; 2000, 56-63.

5. Acharya SK, Batra Y, Bhatkal B, Ojha B, Kaur K, Hazari S, Saraya A, Panda SK: Seroepidemiology of hepatitis a virus infection among school children in Delhi and north Indian patients with chronic liver disease: Implications for HAV vaccination. J Gastroenterol Hepatol 2003, 18:822-827.

6. Mathiesen LR, Skinoj P, Nielsen JO, Parcell RH, Wong D, Ranek L: Hepatitis type A, B and non A non B in fulminant hepatitis. Gut 1980, 21:72-77.

7. Evangelos $A$, Akriviadis EA, Redker AG: Fulminant hepatitis $A$ in intravenous drug users with chronic liver disease. Ann Intern Med 1989, 110:838.

8. Koff RS: Hepatitis A. Lancet 1998, 351:1643-1649

9. Inoue K, Yoshiba M, Yotsuyanagi H, Otsuka T, Sekiyama K, Fujita R: Chronic hepatitis A with persistence viral replication. J Med Virol 1996, 50:322-324.

10. Suzuki K, Yanagi M, Mori-Aoki A, Moriyama E, Ishii KJ, Kohn LD: Transfection of single-stranded hepatitis A virus RNA activates MHC class I pathway. Clin Exp Immunol 2002, 127:234-242.

11. Rueckert RR, Wimmer E: Systematic nomenclature of picornavirus proteins. J Virol 1984, 50:957-959.

12. Feinstone $S M$, Kapikian $A Z$, Purcell RH: Hepatitis A: detection by immune electron microscopy of a virus like antigen associated with acute illness. Science 1993, 182:1026-1028.

13. Cohen Jl, Ticehurst JR, Purcell RH, Buckler-White A, Baroudy BM: Complete nucleotide sequence of wild-type hepatitis $A$ virus: comparison with different strains of hepatitis A virus and other picornaviruses. J Med Virol 1987, 61:50-59.

14. Ruiz AP, Sundqvist L, Garcia Z, Taylor L, Visoná K, Norder H, Magnius LO: Presumed common source outbreak of hepatitis $\mathrm{A}$ in an endemic area confirmed by limited sequencing within the VP1 region. J Med Virol 2001, 65:449-456.

15. Robertson BH, Jansen RW, Khanna B, Totsuka A, Nainan OV, Siegl G, Widell A, Margolis HS, Isomura S, Ito K, Ishizo T, Moritsugu Y, Lemon SM: Genetic relatedness of hepatitis A virus strains recovered from different geographical regions. J Gen Virol 1992, 73:1365-1377.

16. Fugiwara K, Yokosuka O, Imazeki F, Saisho H, Saotome N, Suzuki K, Okita K, Tanaka E, Omata M: Analysis of the genotype determining region of hepatitis A viral RNA in relation to disease severities. Hepatol Res 2003, 25:124-134.

17. Kanda T, Yokosuka O, Kato N, Imazeki F, Fujiwara K, Kawai S, Saisho H, Omata M: Hepatitis A virus VP3 may activate serum response element associated transcription. Scand J Gastroenterol 2003, 38:307-313.

18. Hussain Z, Das BC, Husain SA, Asim M, Chattopadhyay S, Malik A, Poovorawan Y, Theamboonlers A, Kar P: Hepatitis A viral genotypes and clinical relevance: Clinical and molecular characterization of hepatitis A virus isolates from northern India. Hepatol Res 2005, 32:16-24.

19. Vaidya SR, Chitambar SD, Arankalle VA: Polymerase chain reaction based prevalence of hepatitis $A$, hepatitis $E$ and $\Pi T$ viruses in sewage from an endemic area. J Hepatol 2002, 37:131-136.

20. Robertson BH, Khanna B, Nainan OV, Margolis HS: Epidemiologic patterns of wild-type hepatitis A virus determined by genetic variation. J Infect Dis 1991, 163:286-292.

21. Hussain Z, Das BC, Husain SA, Murthy NS, Kar P: Increasing trend of acute hepatitis A in north India: need for identification of high-risk population for vaccination. J Gastroenterol Hepatol 2006, 21:689-693.

22. Das K, Jain A, Gupta S, Kapoor S, Gupta RK, Chakravorty A, Kar P: The changing epidemiological pattern of hepatitis $A$ in an urban population of India: Emergence of a trend similar to the European countries. Eur J Epidemiol 2000, 16:507-510. 
23. Kar P: Hepatitis A virus epidemiology is changing in India. Trop Gastroenterol 1997, 18:45-46.

24. Trey C, Davidson CS: The management of fulminant hepatic failure. In Progress in liver diseases.. 3 edition. Edited by: Popper H, Shaffner F. New York: Grune 1970:282-298.

25. Theamboonlers $A$, Jantaradsamee $P$, Chatchatee $P$, Chongrisawat $V$, Moemula M, Poovorawan Y: Molecular characterization of hepatitis Avirus infections, in the context of two outbreaks in Southern Thailand. Ann Trop Med Parasitol 2002, 96:727-734.

26. Totsuka A, Moritsugu Y: Hepatitis A Virus Proteins. Intervirology 1999, 42:63.

27. Costa-Mattioli M, Monpoeho S, Nicand E, Aleman MH, Billaudel S, Ferre V: Quantification and duration of viremia during hepatitis A infection as determined by real-time RT-PCR. J Viral Hepat 2002, 9:101-106.

28. Hollinger FB, Ticehurst JR: Hepatitis A virus. In Fields Virology.. 3 edition. Edited by: Fields BN, Knipe DM, Howley PM et al. Lippincott-Raven, Philadelphia; 1996:, The A to F of viral hepatitis, (Editorial). Lancet 1990, 336: 1158

29. Hadler SC, Webster HM, Erben JJ, Swanson JE, Maynard J: Hepatitis A in day-care centers: a community-wide assessment. N Engl J Med 1980, 302:1222-1227.

30. Arankalle VA, Chadha MS, Chitambar SD, Walimbe AM, Chobe LP, Gandhe SS: Changing epidemiology of hepatitis $A$ and $E$ in urban and rural India (1982-1998). J Viral Hepat 2001, 8:293-303.

31. Melnick JL: History and epidemiology of hepatitis A virus. J Infect Dis 1995, 171:S2-S8.

32. Yotsuyanagi H, lino S, Koike K, Yasuda K, Hino K, Kurokawa K: Duration of viremia in human hepatitis as determined by polymerase chain reaction J Med Virol 1993, 40:35-38.

33. Hussain Z, Husain SA, Pasha ST, Anand R, Chand A, Polipalli SK, Rehman S, Kar P: Does mutation of hepatitis A virus exist in North India? Dig Dis Sci 2008, 53:506-510.

34. Hussain Z, Das BC, Husain SA, Polipalli SK, Ahmed T, Begum N, Medhi S, Verghese A, Raish M, Theamboonlers A, Poovorawan Y, Kar P: Virological course of hepatitis $A$ virus as determined by real time RT-PCR: Correlation with biochemical, immunological and genotypic profiles. World J Gastroenterol 2006, 12:4683-4688.

35. Feeney C, Bryzman S, Kong L, Brazil H, Deutsch R, Fritz LC: T-lymphocyte subsets in acute illness. Crit Care Med 1995, 23:1680-1685.

36. Gupta M, Jain MR, Parashari A, Singh V, Sharma S: Circulating immune profile in patients with pre-cancer and cancer of the cervix: a cross sectional study among Indian women. Bull Cancer 1993, 80:852-856.

37. Cromeans T, Humphrey C, Sobsey M, Fields H: Use of immunogold preembedding technique to detect hepatitis A viral antigen in infected cells. Am J Anat 1989, 185:314-320.

doi:10.1186/1743-422X-8-254

Cite this article as: Hussain et al:: Immunological and molecular epidemiological characteristics of acute and fulminant viral hepatitis A. Virology Journal 2011 8:254.

\section{Submit your next manuscript to BioMed Central and take full advantage of:}

- Convenient online submission

- Thorough peer review

- No space constraints or color figure charges

- Immediate publication on acceptance

- Inclusion in PubMed, CAS, Scopus and Google Scholar

- Research which is freely available for redistribution

Submit your manuscript at www.biomedcentral.com/submit
Biomed Central 